\title{
Pengaruh tingkat pengangguran, inflasi dan negara sasaran terhadap perdagangan Internasional Indonesia
}

\author{
Siti Hodijah*; Leonardo Simamora \\ Prodi Ekonomi Pembangunan, Fak. Ekonomi dan Bisnis, Universitas Jambi \\ *E-mail korespondensi: sitihodijah@unja.ac.id
}

\begin{abstract}
The purpose of this study was to determine the effect of unemployment and inflation as well as the reasons for choosing target players in carrying out export activities (international trade). This type of research is quantitative research. The data used are secondary data from Indonesia for the 2001-2020 period. The data is processed using data analysis Vector Autoregression or VAR. The results showed that unemployment had a positive and significant effect on inflation and inflation had no significant effect on unemployment. while exports have a positive and insignificant effect on unemployment. And exports and inflation are insignificant.
\end{abstract}

Keywords: Unemployment, Inflation, Target countries, International trade

\begin{abstract}
Abstrak
Tujuan dari penelitian ini adalah untuk mengetahui pengaruh pengangguran dan inflasi serta alasan memilih nengara sasaran dalam melakukan kegiatan ekspor (perdagangan internasional). Jenis penelitian ini adalah penelitian kuantitatif. Data yang digunakan adalah data sekunder Indonesia periode 2001-2020. Data diolah dengan menggunakan analisis data Vector Autoregression atau VAR. Hasil penelitian menunjukkan bahwa pengangguran berpengaruh positif dan signifikan terhadap inflasi dan inflasi tidak berpengaruh sigmifikan terhadap pengangguran. sedangkan ekspor berpengaruh positif dan tidak signifikan terhadap pengangguran. Dan ekspor dan inflasi tidak signifikan.
\end{abstract}

Kata kunci: Pengangguran, Inflasi, Negara sasaran, Perdagangan internasional

\section{PENDAHULUAN}

Fenomena globalisasi menyebabkan interaksi antar negara di berbagai belahan dunia semakin intensif. Intensitas hubungan terutama sangat dipengaruhi oleh kepentingan antar negara untuk saling melengkapi kebutuhan antar satu negara dengan negara lain. Cara untuk memenuhi kebutuhan dari masing-masing negara bergantung pada kegiatan perdagangan internasional mereka. Perdagangan internasional tentu membutuhkan mata uang yang disepakati untuk digunakan dalam transaksi perdagangan yaitu dolar AS (Amerika Serkat). Penggunaan dolar AS menyebabkan pertukaran nilai tukar rupiah terhadap dolar berfluktuasi dari waktu ke waktu. Hal ini dapat menyebabkan terjadinya resiko perubahan nilai tukar mata uang yang timbul karena adanya ketidakpastian nilai tukar itu sendiri (Muzakki, 2015).

Perdagangan internasional adalah salah satu strategi untuk memenuhi kebutuhan. Perdagangan internasional terdiri dari ekspor dan impor. Kegiatan ini juga dilakukan karena adanya perbedaan kebutuhan antara dua negara atau lebih. Hal ini juga identik dengan kajian untuk mencapai kesejahteraan yang lebih luas (mencakup negara). Sejak dahulu berlabuh dari satu negara ke negara lain sudah dilakukan dan bahkan sampai akhirnya memunculkan penjajahan di beberapa negara dunia. 
Salah satu hal yang dapat dijadikan motor penggerak bagi pertumbuhan pun dengan perdagangan internasional. Salvatore menyatakan bahwa perdagangan dapat menjadi mesin bagi pertumbuhan (trade as engine of growth, Salvatore, 2004). Jika aktifitas perdagangan internasional adalah ekspor dan impor, maka salah satu dari komponen tersebut atau kedua-duanya dapat menjadi motor penggerak bagi pertumbuhan. Tambunan (2005) menyatakan pada awal tahun 1980-an Indonesia menetapkan kebijakan yang berupa export promotion. Dengan demikian, kebijakan tersebut menjadikan ekspor sebagai motor penggerak bagi pertumbuhan. Ketika perdagangan internasional menjadi pokok bahasan, tentunya perpindahan modal antar negara menjadi bagian yang penting juga untuk dipelajari. Sejalan dengan teori yang dikemukakan oleh Vernon, perpindahan modal khususnya untuk investasi langsung, diawali dengan adanya perdagangan internasional (Appleyard, 2004).

Ketika terjadi perdagangan internasional yang berupa ekspor dan impor, akan memunculkan kemungkinan untuk memindahkan tempat produksi. Peningkatan ukuran pasar yang semakin besar yang ditandai dengan peningkatan impor suatu jenis barang pada suatu negara, akan memunculkan kemungkinan untuk memproduksi barang tersebut di negara importir. Kemungkinan itu didasarkan dengan melihat perbandingan antara biaya produksi di negara eksportir ditambah dengan biaya transportasi dengan biaya yang muncul jika barang tersebut diproduksi di negara importir. Jika biaya produksi di negara eksportir ditambah biaya transportasi lebih besar dari biaya produksi di negara importir, maka investor akan memindahkan lokasi produksinya di negara importir (Appleyard, 2004).

Penelitian mengenai pengaruh inflasi terhadap nilai tukar rupiah per dollar AS sangat penting dilakukan, tujuannya ialah untuk mengetahui bagaimana hubungan dan seberapa besar pengaruh inflasi dalam mempengaruhi pergerakan nilai tukar rupiah terhadap dollar AS. Pada akhirnya dapat diketahui kebijakan-kebijakan yang dapat diambil untuk menjaga kestabilan nilai tukar rupiah yang berkaitan dengan variabel inflasi (Istiqomah, 2013). Mata uang Dollar Amerika diterima sebagai mata uang yang sering digunakan dalam melakukan perdagangan Internasional, karena Dollar Amerika merupakan mata 2 uang yang kuat serta acuan bagi sebagian besar Negara berkembang lainnya.

Selain itu, Amerika Serikat merupakan partner dagang dominan Indonesia sehingga ketika nilai mata uang Rupiah Indonesia atas Dollar Amerika tidak stabil, maka akan menganggu perdagangan yang berdampak pada kerugian dan Inflasi tersebut menyebabkan daya beli masyarakat terhadap suatu barang akan menurun karena jumlah uang sama pada tahun lalu tidak dapat untuk membeli barang yang sama tahun ini. Hal ini menyebabkan mata uang rupiah terdepresiasi. Krisis yang terjadi pada tahun 1997/1998 telah memberikan dampak negatif terhadap seluruh sektor ekonomi di Indonesia. Depresiasi nilai tukar yang sangat tinggi telah mengakibatkan harga barangbarang impor melambung tinggi dan inflasi meroket hingga mencapai 77,6 persen pada tahun 1998. Depresiasi nilai tukar mengakibatkan banyak industri dalam negeri mengalami kesulitan terutama industri yang bahan bakunya diperoleh dari impor. Kondisi tersebut ikut diperparah dengan besarnya kewajiban hutang luar negeri perusahaan dan perbankan di Indonesia serta kerusuhan sosial. Jadi semua faktor tersebut berakumulasi dan mengakibatkan kegiatan ekonomi mengalami kontraksi yang dalam hingga mencapai -13,1\% pada tahun 1998 (Simorangkir dkk, 2005:45).

Nilai mata uang suatu negara dalam perdagangan internasional tentunya menjadi patokan untuk mendapatkan keuntungan maksimal. Nilai uang dipengaruhi oleh tingkat inflasi, apabila inflasi meningkat maka nilai uang berkurang dan pada gilirannya akan memengaruhi kekuatan mata uang nasional terhadap mata uang internasional (USD).

Permasalahan mengenai penganguuran pun dapat memengaruhi sirkulasi perdagangan internasional. Pengangguran akan menciptakan beban bagi pemerintah 
untuk dalam hal output, memenuhi kebutuhan dan pertumbuhan ekonomi. Applear, Field dan Cobb (2008) menjelaskan dampak hubungan internasional dalam perdagangan internasional dapat meningkatkan pengangguran, hal ini didasari pada negara berkembang dimana biasanya yang cenderung capital intensive, sehingga kegiatan yang bersifat hubungan antar negara kurang cocok di negara berkembang yang mayoritas dengan jumlah tenaga kerja yang berlimpah, terkhusus negara raksasa yang bekerja sama dengan negara terbelakang. Efek samping dari penganguran ini juga dapat menimbulkan adanya negara jajahan secara tidak langsung akibat kepentingan negara raksasa.

\section{HASIL DAN PEMBAHASAN}

\section{Pengangguran, inflasi dan ekspor}

Pengangguran dalam 20 tahun terakhir tercata dalam data BPS 2021 menjelaskan bahwa tingkat penganguran dari tahun ke tahunnya mengalami pasang surut, hal ini juga di ikuti oleh tingkat ekspor indonesia yang tiap tahunnya mengalami pasang surut.

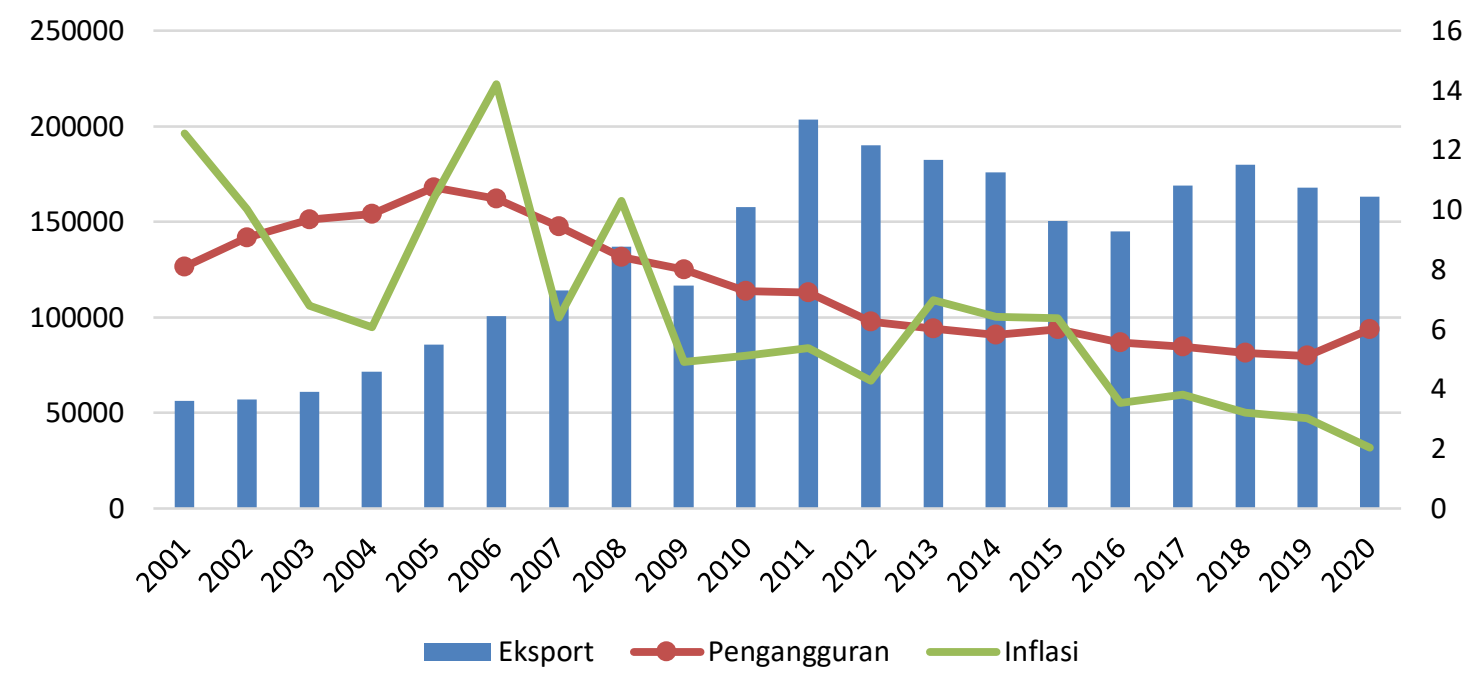

Sumber:Badan Pusat Statistik, 2021 (diolah)

Gambar 1. Pengangguran, inflasi, dan ekspor

Dalam metode analisi model VAR menjelaskan bahwa data tersebut telah lolos uji dengan fiirst difference terbukti dari nilai probabilitinya dibawah $0,0000<0,05$.

Tabel 1. Group unit root test: summary

\begin{tabular}{lcccc}
\hline \hline \multicolumn{1}{c}{ Method } & Statistic & Prob.** & $\begin{array}{c}\text { Cross- } \\
\text { sections }\end{array}$ & Obs \\
\hline Null: Unit root (assumes common unit root process) & & \\
\hline Levin, Lin \& Chu t* & -4.76176 & 0.0000 & 3 & 54 \\
& & & & \\
Null: Unit root (assumes individual unit root process) & & & 54 \\
Im, Pesaran and Shin W-stat & -4.84105 & 0.0000 & 3 & 54 \\
ADF - Fisher Chi-square & 31.2473 & 0.0000 & 3 & 54 \\
PP - Fisher Chi-square & 71.2220 & 0.0000 & 3 & \\
\hline \hline
\end{tabular}

** Probabilities for Fisher tests are computed using an asymptotic Chi

Sumber:Badan Pusat Statistik, 2021 (diolah) 
Data telah lolos stasioner pada derajat pertama dan memenuhi tahapan VECM, selanjutnya akan di uji dengan menggunakan VAR, terlihat dari nilai modulus dibawah angka 1.

Tabel 2. Group unit root test: summary

Roots of Characteristic Polynomial

Endogenous variables: D(E) D(I) D(P)

\begin{tabular}{cc}
\hline Root & Modulus \\
\hline 0.397968 & 0.397968 \\
-0.361345 & 0.361345 \\
0.150740 & 0.150740 \\
\hline
\end{tabular}

No root lies outside the unit circle.

VAR satisfies the stability condition.

Sumber:Badan Pusat Statistik, 2021 (diolah)

Berdasarkan Gambar 2. Invers roots of AR characteristic polynominal menunjukkan Titik tidak keluar dari lingkaran menandakan bahwa model telah memnuhi stabilitas.

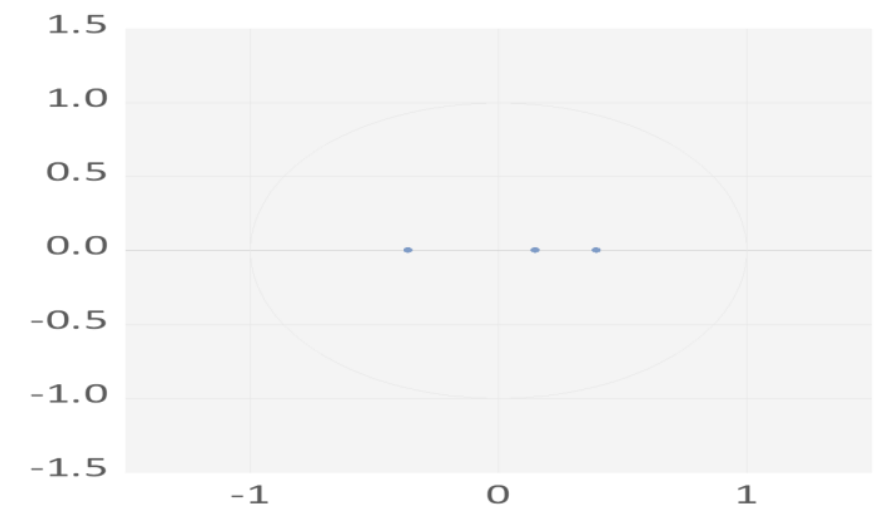

Sumber:Data diolah, 2021

Gambar 2. Invers roots of AR characteristic polynominal

Selanjutnya dengan uji grangger causality test menyimpulkan bahwa eksport dipengaruhi oleh pengangguran namun pengangguran tidak mempengaruhi ekspor. Selanjutnya pengangguran dipengaruhi inflasi namun inflasi tidak dipengaruhi pengangguran.

Tabel 3. Pairwise granger causality tests lag 1

\begin{tabular}{lccc}
\hline \hline Null Hypothesis: & Obs & F-Statistic & Prob. \\
\hline \hline I does not Granger Cause E & \multirow{2}{*}{19} & 3.08285 & 0.0982 \\
E does not Granger Cause I & & 3.07981 & 0.0984 \\
\hline \hline P does not Granger Cause E & \multirow{2}{*}{19} & 0.15035 & 0.7033 \\
E does not Granger Cause P & & 16.8358 & 0.0008 \\
\hline \hline P does not Granger Cause I & \multirow{2}{*}{19} & 8.84581 & 0.0089 \\
I does not Granger Cause P & & 0.09347 & 0.7638
\end{tabular}

Sumber:Data diolah, 2021 
Selanjutnya dengan menguji menggunakan vector eror correction model. Hasilnya didapatkan bahwa coefisien error correction signifikan $\mathrm{C} 1$ sebesar 0,0010 atau lebih kecil dari alfa $5 \%$ dan $10 \%$.

Tabel 4. Estimation method: least squares

\section{Coefficient Std. Error t-Statistic Prob.}

\begin{tabular}{lrrrr}
\hline \hline C(1) & -0.017130 & 0.004650 & -3.683659 & 0.0010 \\
C (2) & -0.039424 & 0.239157 & -0.164845 & 0.8703 \\
C(3) & -0.802511 & 0.259025 & -3.098201 & 0.0045 \\
C(4) & 0.246868 & 0.144307 & 1.710718 & 0.0986 \\
C(5) & 0.244325 & 0.101980 & 2.395807 & 0.0238 \\
\hline
\end{tabular}

Sumber:Data diolah, 2021

Dalam hasil regres VAR memiliki dampak yang signifikan. Kenaikan inflasi $1 \%$ akan menyebabkan peningkatan ekspor $0,24 \%$. Kenaikan penganguran $1 \%$ akan menurunkan ekspor $0,43 \%$.

Tabel 4. Vector error correction estimates

\begin{tabular}{cc}
\hline \hline Cointegrating Eq: & CointEq1 \\
\hline \hline LOG(E(-1)) & 1.000000 \\
& \\
LOG(I(-1)) & 0.532001 \\
& $(0.20965)$ \\
& {$[2.53756]$} \\
LOG(P(-1)) & 0.357177 \\
& $(0.36265)$ \\
C & {$[0.98492]$} \\
-13.41802 \\
\hline
\end{tabular}

Sumber:Data diolah, 2021

$$
\mathrm{Y}=-\mathbf{1 3 , 4 2}+1 \mathrm{LOG}(\mathrm{E}(-1))+\text { 0,53LOG(I(-1)) + 0,36LOG(P(-1)) }
$$

Jumlah hasil konstan, yaitu -13,42 maksudnya jika nilai eksport, inflasi dan pengangguran dianggap konstan, jadi Y tahun 2001-2020 adalah -13,42\%. Ekspor berpengaruh positif terhadap nilai koefisien sebesar 1, artinya setiap kenaikan ekspor $1 \%$ akan menaikkan Y sebesar $1 \%$. Inflasi berpengaruh positif terhadap nilai koefisien sebesar 0,53, artinya setiap kenaikan inflasi $1 \%$ akan meningkatkan Y sebesar 0,53\%. Dan pengangguran berpengaruh positif terhadap nilai koefisien sebesar 0,36. Artinya kenaikan $1 \%$ pengangguran akan meningkatkan Y sebesar $0,36 \%$.

Pada regres diatas di jelaskan bahwa dalam jangka panjang kenaikan pengangguran $1 \%$ akan menaikkan ekspor $0,36 \%$. Dan kenaikan inflasi jangka panjang akan meningkatkan $1 \%$ akan meningkatkan ekspor $0,53 \%$. 
Tabel 5. Regesi jangka panjang

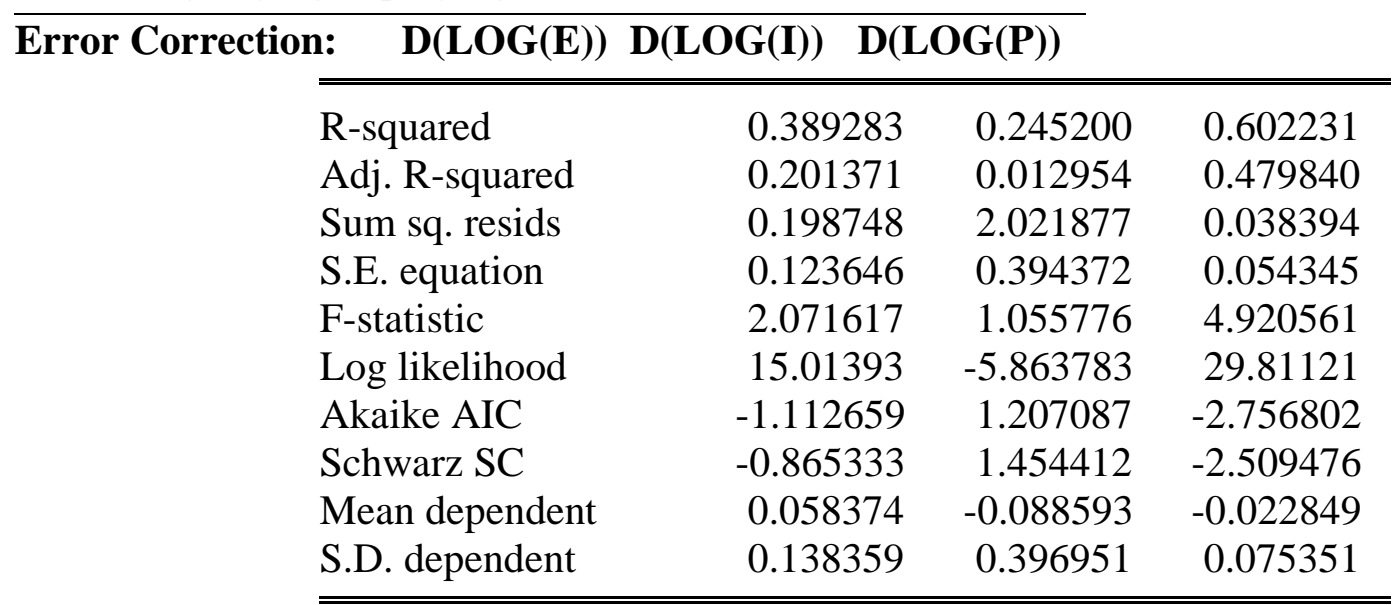

Sumber:Data diolah, 2021

Variabel yang sangat berpengaruh dengan R-squared paling tinggi adalah pengangguran terhadap tiap variabel lainnya yaitu sebesar $60 \%$, selajutnya variabel ekspor sebesar 39\% dan pengangguran sebesar $25 \%$.

\section{Negara sasaran}

Dalam data BPS mencatat sasaran negara yang menjadi tujuan indonesia untuk melakukan ekspor.

\begin{tabular}{rrrrrr}
\hline & \multicolumn{1}{c}{ Asean } & Afrika & $\begin{array}{c}\text { Australia \& } \\
\text { Oceania }\end{array}$ & America & $\begin{array}{c}\text { Eropa, Uni } \\
\text { Eropa }\end{array}$ \\
\hline 2019 & 121108,9 & 4603,4 & 3065,9 & 41676,8 & 16870,1 \\
2018 & 129445,3 & 4782,1 & 3579,9 & 43211,4 & 19253,1 \\
2017 & 119209,3 & 4887,8 & 3264,4 & 41781,2 & 19287,7 \\
2016 & 98536,8 & 4186,3 & 3913,6 & 37776,9 & 18409,3 \\
2015 & 103547,5 & 4759,5 & 4433,5 & 38024,4 & 17388,5 \\
2014 & 124272,1 & 6262,3 & 5738,4 & 39171,6 & 18671,6 \\
2013 & 132926,6 & 5615,5 & 5207,5 & 37341,1 & 18622,4 \\
2012 & 139607,7 & 5713,7 & 5682,8 & 35608,6 & 19724,2 \\
2011 & 147846,6 & 5675,3 & 6303,1 & 39450,8 & 22298,6 \\
2010 & 112152,1 & 3657,0 & 4890,4 & 34262,7 & 18578,1 \\
2009 & 81835,1 & 2802,9 & 3856,7 & 25210,2 & 14551,6 \\
2008 & 95904,9 & 3333,3 & 4820,3 & 30189,1 & 16881,2 \\
2007 & 79092,9 & 2541,9 & 3830,4 & 26674,6 & 14486,9 \\
2006 & 69257,0 & 1985,6 & 3187,7 & 25607,4 & 12861,9 \\
2005 & 58762,5 & 1669,0 & 2588,5 & 22273,1 & 10976,8 \\
2004 & 48170,5 & 1359,4 & 2144,7 & 19818,1 & 9575,3 \\
2003 & 35871,7 & 0 & 2049,7 & 15987,9 & 15143,0 \\
2002 & 32298,5 & 0 & 2170,7 & 16401,6 & 14488,8 \\
2001 & 35670,1 & 1181,9 & 2086,0 & 9132,2 & 8250,8 \\
\hline
\end{tabular}

Sumber:Data diolah, 2021

Data ini menjelaskan bahwa ekspor terbanyak Indonesia adalah di negara negara benua ASEAN, selanjutnya adalah benua Amerika, Eropa dan paling rendah adalah Afrika. Hal ini sudah dipertimbangkan oleh banyaknya keuntungan yang akan di dapat 
setelah diakukannya transaksi ekspor. Benua Asia memiliki jarak yang dekat dengan indonesia sehingga tidak banyak mengeluarkan biaya transportasi eksport prosuk dalam negeri. Benua Amerika sebagai benua adikuasa sekaligus sebagai negara super power dan menarik perhatian banyak negara untuk melakukan eksort. Selanjutnya adalah benua eropa, perkembangan teknologi dan ilmu di eropa sangatlah cepat sehingga menjadi fokus pertimbangan banyak negara untuk melakukan ekspor dibenua tersebut. Benua australia dan afrika merupakan benua yang tertinggal, sehingga para negara lain enggan melakukan ekspor di benua ini dan bahkan ekspor terhadap negara dibenua tersebut hanya didasari oleh tidak hilangnya hubungan antar negara dan sosial kemanusiaan untuk membantu, namun tidak untuk mengharapkan bisnis dan untung yang besar.

\section{KESIMPULAN DAN SARAN}

\section{Kesimpulan}

Peningkatan ekspor dapat memengaruhi pengangguran, namun hal ini belum tentu berpengaruh terbalik antara pengangguran dengan ekspor. Inflasi dapat dipengaruhi oleh pengangguran, namun pengangguran tidak berpengaruh signifikan terhadap inflasi atau berbanding terbalik. Ekspor terhadap inflasi tidak berpengaruh signifikan.

Negara tujuan untuk ekspor barang perlu mempertmbangakn dan mengelompokkan bisnis dan sosial kemanusiaan. Untuk motif bisnis akan menjadikan negara sasaran ekspor yang jaraknya dekat, negara maju dan mendapat banyak feedback kerjasama. Sedangkan motif sosial akan menjadikan negara tujuan hanya sebatas bantuan untuk memnuhi kebutuhan dalam negari.

\section{Saran}

Dalam meningkatkan ekspor untuk bersaing di dunia internasional, secara tidak langsung mengurangi pengangguran walau peningkatan pengangguran tidak signifikan terhadap ekspor. Sehingga pemerintah perlu untuk meningkatkan ekspor.

Inflasi juga demikian, permasalah inflasi bukanlah disebabkan oleh rendahnya ekspor namun berpengaruh signifikan terhadap pengangguran. Menjaga stabilitas harga akan menyeimbangkan harga dalam negari untuk tidak menimbulkan masalah baru seperti pengangguran.

Negara tujuan ekspor negara dalam perdagangan internasional perlu membedakan motif bisnis dan sosial kemanusian, ketimpangan antar negara maju dan berkembang yang cukup sulit diatasi perlu dipahami lebih dalam untuk keadilan dunia.

\section{DAFTAR PUSTAKA}

Appleyard, D., Field, A., \& Cobb, S. (2006). International economics. 5th Edition. New York: Mc Graw.

Appleyard, Dennis R., Alfred J. Field, Jr., Steven L. Cobb. (2008). International economics, Sixth Edition. NY: The McGraw-Hill Companies, Inc: New York

BPS. (2021). Laju pertumbuhan y-on-y-PDRB atas dasar harga konstan menurutpengeluaran 2010 diakses dalam https://bps.go.id/, Tanggal 21 Februari 2020, Pukul 13.00 WIB

Dwi Wulandari, Patricia Intan Karonesia. (2010). Pengaruh inflasi dan investasi terhadap nilai tukar rupiah di Indonesia Tahun 2003-2019. Jurusan Pendidikan Ekonomi, Fakultas Ekonomi Universitas Negeri Medan, 1-12

Febryastuti Retno. (2019). Pengaruh keterbukaan perdagangan internasional dan 
pertumbuhan ekonomi terhadap pengangguran di ASEAN-5, 1996-2017. Journal of Economics Development Issues, 2(01), 19-25. https://doi.org/ https://doi.org /10.33005/jedi.v2i01.23

Fiki Ariyanti. (2021). Panic buying akibat corona, belanja sembako di swalayan dibatasi. ini daftarnya! Dikases dalam https://www.cermati.com, Tanggal 23 Maret 2020.Pukul 12.30 WIB

Istiqomah. (2013). Perbandingan metode ekstraksi maserasi dan sokletasi terhadap kadar piperin buah cabe Jawa (piperis retrofracti fructus). Skripsi. Jurusan Farmasi UIN Syarif Hidayatullah Jakarta: Jakarta

Kemenag. (2021). Data expor dan impor, diakses dalam https://statistik.kemendag.go.id/ export-import, Tanggal 21 Februari 2020, Pukul 13.00 WIB

Muzakki. (2015). Pengaruh corporate social responsibility dan capital intensity terhadap penghindaran pajak (studi empiris pada perusahaan manufaktur yang terdaftar pada bursa efek indonesia Tahun 2011-2013). Semarang: Universitas Diponegoro.

Salvatore, Dominick. (2004). Theory and problem of micro economic theory. 3rd edition. alih bahasa oleh Rudi Sitompul. Erlangga: Jakarta

Simorangkir. (2003). Etika: bisnis, jabatan, dan perbankan. Asdi Mahasatya: Jakarta

Sulistiana, Ineu. (2017). Model vector auto regression (VAR) and vector error correction model (VECM) approach for inflation relations analysis, gross regional domestic product (GDP), world tin price, Bi Rate and Rupiah exchange rate. Integrated Journal of Business and Economics, 1(2), 17-32.

Syahputra, R. (2017). Analisis faktor-faktor yang mempengaruhi pertumbuhan ekonomi di Indonesia. Jurnal Samudra Ekonomika, 1(2), 183-191. https://doi.org/10.1234/ jse.v1i2.334

Tambunan, STB. (2005). Kebisingan di tempat kerja (occupational noise). C.V. Andi Offset: Yogyakarta 